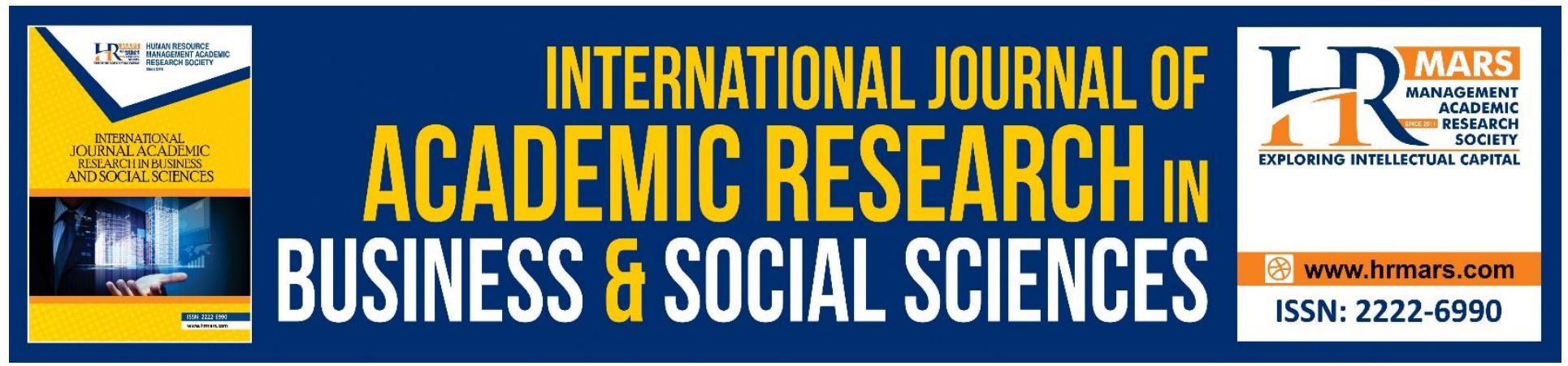

\title{
Consumer Behaviour and Insurance Claim Fraud in Malaysia
}

Fauzilah Salleh, Dgku Noor Hazzarita Ag Kassim, Ahmad Shukri Yazid, Norfadzilah Rashid

To Link this Article: http://dx.doi.org/10.6007/IJARBSS/v8-i12/5057

DOI: $10.6007 /$ IJARBSS/v8-i12/5057

Received: 18 Nov 2018, Revised: 21 Dec 2018, Accepted: 28 Dec 2018

Published Online: 29 Dec 2018

In-Text Citation: (Salleh, Kassim, Yazid, \& Rashid, 2018)

To Cite this Article: Salleh, F., Kassim, D. N. H. A., Yazid, A. S., \& Rashid, N. (2018). Consumer Behaviour and Insurance Claim Fraud in Malaysia. International Journal of Academic Research in Business and Social Sciences, 8(12), 586-598.

Copyright: (C) 2018 The Author(s)

Published by Human Resource Management Academic Research Society (www.hrmars.com)

This article is published under the Creative Commons Attribution (CC BY 4.0) license. Anyone may reproduce, distribute, translate and create derivative works of this article (for both commercial and non-commercial purposes), subject to full attribution to the original publication and authors. The full terms of this license may be seen at: http://creativecommons.org/licences/by/4.0/legalcode

Vol. 8, No. 12, 2018, Pg. 586 - 598

http://hrmars.com/index.php/pages/detail/IJARBSS

JOURNAL HOMEPAGE

Full Terms \& Conditions of access and use can be found at http://hrmars.com/index.php/pages/detail/publication-ethics 


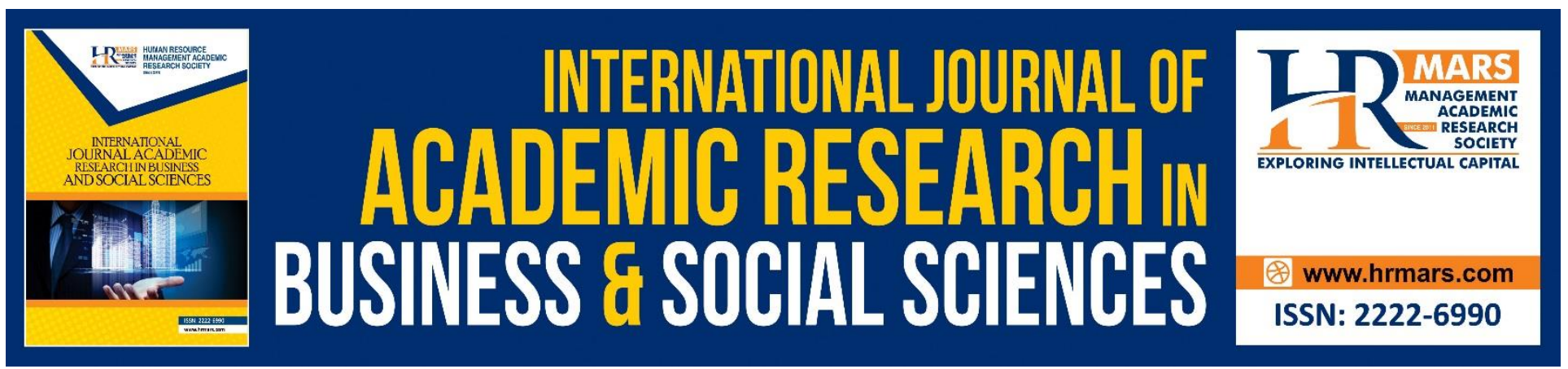

\title{
Consumer Behaviour and Insurance Claim Fraud in Malaysia
}

\section{Fauzilah Salleh, Dgku Noor Hazzarita Ag Kassim, Ahmad Shukri Yazid, Norfadzilah Rashid}

Faculty of Economics and Management Sciences, Universiti Sultan Zainal Abidin, 21300 Kuala Nerus, Terengganu, Malaysia

Corresponding Author: drasyrafafthanorhan@gmail.com

\begin{abstract}
This review paper aims to determine the factors influencing the attitudes of consumers towards insurance claim fraud. In this research, data review was conducted on 60 articles associated with this study's objectives according to experts' views and researchers' experience. It was shown in this research's primary finding that economic issues, moral hazard, and perceived fairness are the elements which will result in insurance claim fraud. This has validated the influence posed by consumer behaviour on insurance claim fraud. However, the estimated insurance claim fraud data provided by Bank Negara Malaysia (BNM) rather than the actual data, along with the obstacles of acquiring data from consumers were the limitations in this research.
\end{abstract}

Keyword: Insurance Claim Fraud, Consumer Behaviour, Insurance

\section{Introduction}

As of recently, insurance has become a necessity for most people. However, comprehension regarding insurance is important before purchase. The definitions of insurance are various. One of them is that it is one of business services which provide protection to an individual from financials losses when a premium is purchased. Through insurance, the risks which may be faced by its consumer is transferred to the insurance corporation in order to ensure zero risks. Furthermore, the principle of insurance is that once the premium is purchased by the policyholder, other policyholders will also carry the burden of unexpected financial loss in equal amount (Clare et al., 2000). Another definition is that insurance is an agreement reached between insurer and the policy buyer for coping with risks. Transparency of the agreement about the conditions having to be concealed in any case is the primary condition of this (Manuel et al, 2002).

Providing protection to consumers from risks is the most crucial role of insurance. However, prediction of loss is impossible due to its uncertainty. Therefore, insurance aids the reduction of financial loss which is associated with the preceding event. The purchase of insurance is thought as a 
INTERNATIONAL JOURNAL OF ACADEMIC RESEARCH IN BUSINESS AND SOCIAL SCIENCES Vol. 8, No. 12, Dec, 2018, E-ISSN: 2222-6990 @ 2018 HRMARS

waste as protection would not be provided without any occurrence of loss. In contrary to this perception, through insurance, consumers will receive valuable coverage which help minimize their financial loss. In the case of loss not being protected in the policy term, protection will be guaranteed for the policyholder. Moreover, it is mentioned by several individuals that an element of gambling is present in insurance purchase. For this reason, the provision of insurance is so that current risks can be transferred to insurance organizations (Clare et al., 2000).

In the case of families, stabilization can be acquired through the system of insurance. To illustrate this, through the insurance assistance in alleviating loss, families will gain the strength for life survival after the occurrence of the loss. Besides, as insurance also assists in business planning, it is beneficial in the business field. With the protection provided by insurance agencies, the possibility for investment in business among business operators is getting higher. With this, revenue can be increased for the economy through business expansion and construction, which can be specifically achieved by increasing the number of branches. Moreover, a good reputation can be achieved by an organization in the economic view through insurance. Reinvestment of the collected premiums in ventures and businesses is also possible. As a result, a business can be sustained through investment in the economy by purchasing raw services and materials (Clare et al., 2000).

However, issues do occur in the insurance industry, especially insurance claim fraud. This refers to any act of fraud with the purpose of profiting from the provision of insurance. The primary factor which leads to this problem is the attempt of the claimant to receive benefit or coverage they do not face any loss. This problem will also occur when the guidelines and the guidelines on the sum insured appropriate for the insured are not followed by the insurer. Due to prevalent case of fraud occurring in this industry, there has been numerous fraudulent claims which, for example, address on false information of received payment and excessive amount of loss. This issue usually occurs due to fake claims issued regarding accidents which have not taken place yet. In the case of excessive amount of loss, this occurs due to the increase of the number of hospital's facilities demanded, which results in the increase of medical bills. As for false information of received payment receive, it stems from the insurance provider. This results in false treatment provided by hospitals to patients and unnecessary charges for treatments which are not even provided to them. (http://www.piam.org.my/consumer/fraud-reprorting/)

According to the previous studies, insurance claim fraud is described as a criminal act which is not only proven through a reasonable doubt. Furthermore, the intentional act of profiting from an insurer under misinterpretation of material or fraudulence is prohibited by law (Derrig and Krauss, 1994). In fact, the second largest white collar crime which takes place in the United States after tax evasion is insurance fraud (Dean, 2004; Carris and Colin, 1997). This issue has also become prevalent on the global level (Dionne, 2000), therefore causing various members of the professional and academic communities to be constantly concerned about it (Dean, 2004; Lamb, 1999; Baldock, 1997; Niemi, 1995). Billions of dollars' annual losses caused by insurance fraud is expected to occur in the financial world (Dean, 2004). 
It can be concluded from the results of previous studies that insurance claim frauds are the issue which has been causing serious concerns as of recently. Awareness of this issue and effort in determining the influencing factors of the attitudes of consumers towards insurance claim fraud are high important.

\section{Literature Review}

In this research, the association between insurance claim fraud in insurance industry and attitudes of consumers was examined. Insurance is described as an agreement created between the policyholder who purchase the policy for risk coverage, and the insurer. Furthermore, absolute trust is one of the principles in insurance, where honesty regarding information related to the coverage is essential in the agreement in any case. However, dishonesty is often committed by many customers through fraud in order to obtain the claim from insurance industry (Manuel et al., 2002). As mentioned previously, insurance claim fraud is a serious issue occurring in the insurance industry. There has also been a significant increase in the rate of this issue yearly (Irfan Bashir et al., 2014), resulting to numerous investigations into this issue as it causes burden on financial institutions (Tseng \& Kang, 2014). Based on this research results, it can be seen that insurance claim fraud is an extremely unethical behavior which negatively impacts the insurance industry (Tseng, Kang, \& Chung, 2014).

\section{Insurance claim fraud}

Attitudes of consumers, specifically economic obstacles, moral hazard, and perceived fairness in the agreement for insurance are the factors of insurance claim fraud. Furthermore, besides negative perceptions towards insurance institution, social or ethical environment play a role in this issue (Tennyson, 1997). Insurance claim fraud is also described as consumer's negative attitude associated with the experience and perception of consumers in insurance claim fraud. It is also referred to their tolerance towards the exaggeration of this issue. Moreover, the negative attitude of consumers, in which they give false information about themselves when agreement of the policy is made, is the factor of this issue (Tseng \& Su, 2013). They also highlight that insurance claim fraud is also the result of consumer's ethical attitude, and based on the results of other research, it can be seen that other researchers have also reached the agreement that fraud is a wrong action

Insurance claim fraud also happens when consumers are not able to profit from insurance companies (Lu-Ming Tseng, Mei Fang Shih, 2012). It is possible that this is the negative perception that consumer has when it comes to insurance companies. Equality in the amount of claim and amount of premium is important. This is in a sense that the amount of claim is lower than the amount of premium, which will cause dissatisfaction among consumers. This would result in them committing insurance claim fraud. However, it is important for insurers to ensure the presence of additional coverage and premium by enquiring the policy holder in the prevention of inequality in the policy agreement. In addition, the whole system of insurance industry can be negatively affected by fraudulent insurance claim, as many consumers will eventually stop paying for insurance company (Mommaerts, 2015). Some of consumers perform fraudulent insurance claim on purpose due to the long-term premium purchase. This results in their tendency to commit insurance claim fraud (Gepp et al., 2012). 


\section{Consumer Behaviour}

Consumer behavior refers to the study of consumers and their methods of selection of services and products for their life convenience (www.marketingteacher.com). Bolino, Klotz and Turnley (2013) and Huppertz et al. (1978) agree that consumer's perceived fairness is the primary factor which leads to consumers committing insurance claim fraud. Furthermore, due to the unfair treatment given to insurers, this factor has eventually played a highly crucial role (e.g. inequality in deductible amount), due to the possibility that it will become more prominent. It is also found by some researchers that consumers' perceived fairness is the influencing factor of their attitudes toward insurance claim fraud (Dean, 2004). To illustrate this, Brinkmann (2005) highlights that excessive charge is made on the premium by insurers, which encourages consumers to commit insurance claim fraud.

Moral hazard is another influencing factor of consumer's attitudes towards insurance claim fraud. This refers to the possibility that consumers would seek for claims which policies do not create a coverage on (e.g. claims for natural disasters). Furthermore, the claims for non-covered loss is due to three factors. The first factor is the significant association between insurance claim fraud and information asymmetry (Dionne, 2000; Shavell, 1979). Information asymmetry refers to unbalance in terms of the amount of private information known by a party compared to the information known by the other (Chiappori and Salanie, 2000; Browne and Doerpinghaus, 1993). Moreover, Dionne and St-Michel (1991) highlight that, with the presence of high information asymmetry (e.g. illnesses which is hard to identify), insurance coverage will increase due to the long duration of worker's absence from work.

Stiglitz (2009) states that a person who purchases life insurance is more aware of their health more than insurance companies do. This will lead to negative attitudes shown by policyholders, which causes displeasure among insurers. Claims for uncovered loss are sought by most people who make agreement on car insurance policy. Furthermore, the factor of insurance claim fraud is because consumers do not feel guilty of cheating (Ferrell et al., 2002). The possibility of getting caught cheating, ethical climate, norms, and self-interests are the factors of the ethical decisions made by consumers (Vitell \& Muncy, 2005; Trevino et al., 1991). Moreover, the request of claims for noncovered damages will depend on several policyholders who think that they are in charge of it. In conclusion, consumers' behavioral intention is directly influenced by ethical judgment (O'Fallon and Butterfield, 2005).

National Fraud Strategy highlights that economic obstacles, which are the current challenge among consumers, are the factors of insurance claim fraud. Due to economic fluctuation, consumers will be coerced into committing insurance claim fraud (e.g. faking a car accident to file a claim from motor policy). Consumers also cause damage on their own property in order to create claims for extra fund from insurance company to cover their expenses. Meanwhile in the business field, insurance claim fraud is committed by business managers by burning their company's building on purpose in order to obtain compensation from insurance organization for their business loss recovery. 
In the decision made by insurance organizations, a number of factors of the customer's custom site and insurance claim fraud are taken into consideration. According to Adam's equity theory, equality in the amount distributed to consumers is of high importance in the policy which will be purchased by consumers. Therefore, accurate information regarding the policy which will be bought by consumers should be provided by insurance organizations in order to avoid confusion on the offers provided. Therefore, honesty between consumers and insurance organizations is important as the factor preventing consumers from committing insurance claim fraud (Tseng \& kuo, 2014; Burhan, Salleh, \& Burhan, 2015)

Based on the theory's attribution, the cause and the effect which influence customers' decisionmaking in this matter are related to each other. This is due to its attribution for evaluation of consumers' perception on the assessment of price (Tseng \& Kang, 2014). According to the morale hazard on consumers' purchase of an insurance policy, it can be seen that their lack of scrupulousness regarding the policies is done on purpose, and they do not give the information needed by insurance organizations (Mahito Okura, 2013).

Salespeople are capable of helping consumers decide on the reliability of insurance organizations. Furthermore, this assistance does not lead to insurance claim fraud, as no evidence has been found by researchers on this matter (Tseng \& Su, 2013)

\section{Theoretical Framework}

In this paper, economic obstacles, moral hazard, and perceived fairness were the independent variables, while insurance claim fraud was the dependent variable. Figure 1 shows the theoretical framework of this study:

Consumer Behavior

1. Perceived Fairness

2. Morale Hazard

3. Economic Difficulty
Insurance Claim

Fraud

Figure 1: Framework of consumers' moral hazard, perceived fairness, and economic obstacles 
INTERNATIONAL JOURNAL OF ACADEMIC RESEARCH IN BUSINESS AND SOCIAL SCIENCES

Vol. 8, No. 12, Dec, 2018, E-ISSN: 2222-6990 @ 2018 HRMARS

\section{Methodology}

From Scopus database, 949 results were detected using TITLE-ABS KEY (insurance AND claim AND fraud) and among of them only one of many result is detected from Malaysia researcher. In order to increase the number of results for review analysis, we used Google Scholar database. The result appeared from Google Scholar database is 13 after typing "insurance claim fraud" + "Malaysia". Apart from that, we also collect information from other sources of Bank Negara Malaysia and national conferences. In sum, 60 papers were identified meet with the scope of the study and will be addressed for further investigations. Publication of these articles dated around 2007-2017. 55\% of them were associated with consumer's attitudes, while $45 \%$ of them were associated with other influencing factors of insurance claim fraud. For data collection, qualitative method was implemented in $51.67 \%$ of the articles, while quantitative method was used in the remaining article.

Questionnaire survey was conducted on 210 adults from Taiwan, followed by data collection (LuMing Tseng and Mei-Fang Shih, 2012). 255 participants, who consisted of full time civil workers at Taiwan's Agricultural Research Institutes, were chosen. Based on the answers provided in the overall 210 questionnaires, 82.4 percent response rate was recorded. Based on a study by Kathryn Flynn (2016), qualitative method was implemented, and interviews were performed with managers from Australia's largest private health insurance funds organization, who were associated with fraud, and experts in areas associated with health fraud detection.

Besides, based on the articles by Isaac Akomea-Frimpong et al., (2016), primary and secondary information from 39 insurers in Ghana were acquired in this paper. In order to identify the association between insurance fraud variables and financial performance, a multiple regression model was involved. Survey questionnaires were used for collection of primary data from insurance organizations, while secondary data of insurance organizations' annual financial statements were acquired from NIC in 2014. Questionnaires were used as a means of data collection in many investigations on this matter.

With the increase of insurance coverage for Malaysians, there was a continuous improvement occurring in the life insurance industry. In 2016, the overall amount insured by all types of policies was 1.3 trillion. However, the figure in 2015 was $5 \%$ higher compared to the figure in the year before, which was 1.24 trillion. This investigation was also based on qualitative method. In this method, information on the amount of purchase which consumers made from the insurance policy in Malaysia were obtained. Those data originated from Bank Negara Malaysia (BNM). Malaysian citizens, who were estimated to be 32,050 persons in 2017, were purchasers of insurance policy and the target population of this study. As for the population of this study's sample, 45 percent $(16,672$ persons) of the respondents owned insurance products, while 15 percent (5557.46) owned Takaful insurance. 
INTERNATIONAL JOURNAL OF ACADEMIC RESEARCH IN BUSINESS AND SOCIAL SCIENCES Vol. 8, No. 12, Dec, 2018, E-ISSN: 2222-6990 @ 2018 HRMARS

Table 1: Insurance Claim 2014-2017 Source: Bank Negara Malaysia, 2017

\begin{tabular}{|c|c|c|c|c|c|c|c|c|}
\hline \multicolumn{2}{|c|}{$\begin{array}{l}\text { End } \\
\text { period }\end{array}$} & \multirow{2}{*}{$\begin{array}{c}\text { Marine, } \\
\text { aviation, } \\
\text { transit }\end{array}$} & \multirow[t]{2}{*}{$\begin{array}{l}\text { All risk and } \\
\text { engineering }\end{array}$} & \multirow[t]{2}{*}{ Fire } & \multirow{2}{*}{$\begin{array}{c}\text { Medical } \\
\text { expenses/ } \\
\text { personal } \\
\text { accident }\end{array}$} & \multicolumn{3}{|c|}{ Motor } \\
\hline & & & & & & $\begin{array}{l}\text { Act } \\
\text { cover }\end{array}$ & Others & Total \\
\hline \multirow[t]{2}{*}{2014} & $1 \mathrm{H}$ & 38.5 & 47.3 & 29.1 & 42.5 & 316.7 & 51.7 & 76.2 \\
\hline & $2 \mathrm{H}$ & 41.5 & 51.5 & 37.2 & 42.5 & 209.6 & 52.1 & 71.1 \\
\hline \multirow[t]{2}{*}{2015} & $1 \mathrm{H}$ & 35.2 & 123.6 & 25.5 & 36.2 & 219.7 & 53.1 & 74.0 \\
\hline & $2 \mathrm{H}$ & 42.2 & 76.5 & 34.6 & 39.7 & 209.2 & 51.7 & 71.3 \\
\hline \multirow[t]{2}{*}{2016} & $1 \mathrm{H}$ & 33.7 & 50.3 & 35.2 & 45.3 & 123.0 & 57.6 & 66.1 \\
\hline & $2 \mathrm{H}$ & 34.9 & 50.0 & 36.7 & 46.5 & 124.1 & 56.9 & 66.2 \\
\hline 2017 & $1 \mathrm{H}$ & 43.0 & 85.4 & 18.5 & 50.8 & 151.7 & 60.1 & 72.1 \\
\hline
\end{tabular}

Based on the official estimates above, there was no concern by any governmental bodies or authorities regarding the occurrence of insurance claim fraud in Malaysia. It was estimated by The Insurance Services Malaysia Berhad (ISM), that $f 102$ million (RM500 million) were expended annually for insurance claims fraud in Malaysia (Business Time Online, 2008). The approximation of this amount was obtained from Malaysia's insurance market in accordance to 17 percent of the overall $\mathrm{f613}$ million (RM3 billion) annual claims. Moreover, the seriousness of the insurance claim fraud issue was highlighted by the Head of claims Allianz General Insurance Co (M) Bhd, Jayapragash Amblavanar, and there were six fraud cases reported monthly from 2014 to 2016 (The Star, 2017; Burhan et al., 2017).

\section{Research Findings}

Table 2: Percentages of participants who purchased the insurance

\begin{tabular}{cc}
\hline AGE & $\%$ \\
\hline $18-30$ years & $45 \%$ \\
$31-39$ years & $35 \%$ \\
$40-49$ years & $15 \%$ \\
$50-59$ years & $5 \%$ \\
\hline
\end{tabular}

According to previous investigations, data collection regarding the percentage of insurance consumers for life-protection was made. Based on the table above, the consciousness among Malaysian citizens regarding self-protection could be seen. Furthermore, it was indicated that consumers of insurance policy mostly comprised of people from the age group of 18 to 30 years old. People of this group represented $45 \%$ of the overall Malaysian citizens (Berita Harian, 2017). The percentages of the participants who purchased the insurance are displayed below:

According to the table above, the participants with higher consciousness regarding their life protection consisted of people from the age group of 18 to 30 years old in average. From here, it can be seen that young people had higher knowledge and consciousness of this matter. As for those from 
INTERNATIONAL JOURNAL OF ACADEMIC RESEARCH IN BUSINESS AND SOCIAL SCIENCES Vol. 8, No. 12, Dec, 2018, E-ISSN: 2222-6990 @ 2018 HRMARS

the age group of 31 to 39 years old in average, 35\% of them had consciousness regarding their life protection. This created a difference of $10 \%$ when compared to the percentage of people from the former age group, which was $45 \%$. Furthermore, it was found that consumers' consciousness of life protection decreased at the age of 40 to 49 years old. The same case occurred to those from the age group of 50 to 59 years old. This could be seen from a mere $5 \%$ of people of these age groups were found to be conscious of the significance of insurance.

Table 3: Insurance Claim, sources by Bank Negara Malaysia 2017

\begin{tabular}{lcccc}
\hline & $\mathbf{2 0 1 5}(\mathbf{R M})$ & $\mathbf{2 0 1 6}(\mathbf{R M})$ & DIFFERENT(RM) & GROWTH \\
\hline Death & 114 million & 1.2 billion & 80 million & $7.0 \%$ \\
Disability & 126 billion & 85 million & $(40299168)$ & $-31.9 \%$ \\
Medical & 3.15 billion & 3.41 billion & 254353479 & $8.1 \%$ \\
Bonuses & 3.61 billion & 3.58 billion & $(32090713)$ & $-0.9 \%$ \\
Others & 1.15 billion & 1.36 billion & 209497835 & $18 \%$ \\
Total & 918 billion & 9.66 billion & 471697790 & $5.1 \%$ \\
\hline
\end{tabular}

Furthermore, there has been an increase in the overall number of participants who purchased insurance for their life protection since 2015, which resulted in a 5\% increase in 2016 (Sinar Harian, 2017). From this, it can be seen that the consciousness regarding this matter among Malaysia citizens has become more prominent. Therefore, knowledge on the capability of insurance company of providing maximum advantage and benefit to consumers is important.

Based on Table 3, there had been several changes occurring between 2015 and 2016 specifically in the increase and decrease of the frequency of insurance plan purchase. From here, it could be seen that the increase of possibility for consumers to commit insurance claim fraud was dependent on three factors. Besides, when excessive amount of claims was requested by the participant, it would possibly result in the deterioration of insurance industry. Moreover, before any claim was made by participants, investigation would be conducted by the adjuster in order to guarantee the genuineness of the claims. This was because in some cases, consumers had the tendency to commit insurance claim fraud in order to profit from the claim.

It could be seen from the table of this study that there was an excessive amount of claims which insurance organizations needed to spend for the insured. If these situations continue for a long term, insurance organizations will have to face various adverse impacts. According to the table, medical insurance is the particular type of insurance which requires insurance organizations to pay higher average expense for claims. In fact, consumers of medical insurance are knowledgeable of the advantages and benefits they could obtain from insurance organizations.

\section{Discussion}

Based on the results analysis of this study, it can be seen that insurance was purchased mostly for the protection of the consumers' lives, which indicates the high consciousness of Malaysian citizens 
regarding their life protection. It is implied that the knowledge regarding the aspects of life where protection is needed has been instilled in the consumers since young ages. Based on the study's results, as for people from the group of average age between 31 to 39 years old, $35 \%$ of them had the consciousness regarding their life protection. This created a difference of $10 \%$ when compared to the percentage of those from the group of average age from 18 to 30 years old, which was $45 \%$. Meanwhile, the consciousness started to decrease when consumers had reached the age from 40 to 49 years old, which was the same as those who reached the age from 50 to 59 years old. To illustrate, there was a merely $5 \%$ of people from these groups of age who had the consciousness and knowledge of the significance of insurance. Additionally, there had been an increase in the overall number of consumers who purchased insurance for their protection since 2015 , which resulted to $5 \%$ increase in 2016.

Several changes can be seen in 2015 and 2016. As seen from the table, the possibility for consumers to commit insurance claim fraud was present. Furthermore, with excessive amount of claims made by policyholder, it would lead to deterioration of the insurance industry. Therefore, based on the research conducted, it was possible for negative consequences to occur from consumers' attitudes towards insurance claim fraud. Specifically, the factors which would lead to insurance claim fraud in Malaysia are consumers who purchase insurance for their life protection and obtain specific information from Central Bank Malaysia. This issue may occur due to the independent variables of consumer's attitudes. To counteract this issue, strategies are needed for the insurer to avoid repetition of the same issue in the future. As for the contributions of this study, it has provided information regarding the occurrence of insurance claim fraud in Malaysia, which could be used for implementing strategies of prevention against this issue, and for prevention against loss of billion RM in our country.

\section{Limitation of Study}

There were several challenges faced during the completion of this study. One of the primary challenges was when information from Bank Negara Malaysia (BNM) on insurance claim fraud was being obtained. To illustrate this, instead of the actual data on this matter, BNM merely conducted an estimation of the data. The information provided was also outdated. Furthermore, this information could only be accessed by several authorities due to its confidentiality. National security was involved in the information, such as consumer's personal information. Such information might be tampered by irresponsible parties, if known publicly.

Another limitation of this study were the obstacles faced when data was being acquired from the insurance purchasers. One of the methods implemented during this phase of the investigation was the interview with the lectures from Faculty of Economy and Science Management at UniSZA. Specifically, time constraint for interview was the difficulty faced during this phase, provided that the lecturers had high commitments in the university. Moreover, the information given by them was often incomplete as they were concerned on the possibility of misuse of the information. Therefore, it is suggested that another researcher conducts an investigation regarding the consciousness of 
INTERNATIONAL JOURNAL OF ACADEMIC RESEARCH IN BUSINESS AND SOCIAL SCIENCES

Vol. 8, No. 12, Dec, 2018, E-ISSN: 2222-6990 C 2018 HRMARS

insurance claim fraud in the future. It is also recommended that improvement is performed on the framework for BNM so that the framework for the community can be used.

\section{Conclusion}

In this research, the association between consumer's attitudes toward insurance claim fraud was identified. Based on the results of previous studies, insurance claim fraud was found to be a grave issue worldwide due to the adverse impacts posed by consumer's attitudes. According to empirical research, the increase in the amount of insurance claim fraud committed by insurance purchasers has been indicated. This issue will lead to economic problem on the global level. Moreover, based on this investigation, there are approximately billions of dollar financial world losses, which occur annually due to insurance claim fraud.

Based on the discussion of this paper, instead of providing false information, consumers are responsible in providing genuine information about themselves to the insurance company. Furthermore, it is indicated from the application of Adam's equity theory that evaluation on equality in the amount provided to insurance purchasers is important in its policy. As for insurance organizations, accurate information regarding the policy which will be bought by consumers should be provided in the prevention of confusion regarding the offers by insurance company.

Last but not least, it can be concluded in this study that there is a positive association between consumer's attitudes and the influences they pose on insurance claim fraud.

\section{References}

Akomea-Frimpong, I., Andoh, C., \& Ofosu-Hene, E. D. (2016). Causes, effects and deterrence of insurance fraud: evidence from Ghana. Journal of Financial Crime, 23(4), 678-699.

Baldock, J. (1997). Social care in old age: more than a funding problem. Social policy \& administration, 31(1), 73-89.

Bashir, I., \& Madhavaiah, C. (2014). Determinants of young consumers' intention to use Internet banking services in India. Vision, 18(3), 153-163.

Bolino, M. C., Klotz, A. C., Turnley, W. H., \& Harvey, J. (2013). Exploring the dark side of organizational citizenship behavior. Journal of Organizational Behavior, 34(4), 542-559.

Brinkmann, J. (2005). Understanding insurance customer dishonesty: Outline of a situational approach. Journal of Business Ethics, 61(2), 183-197.

Browne, M. J., \& Doerpinghaus, H. I. (1993). Information asymmetries and adverse selection in the market for individual medical expense insurance. Journal of Risk and Insurance, 300-312.

Burhan, N. A. S., Salleh, F., \& Burhan, N. M. G. (2015). National intelligence and private health expenditure: Do high IQ societies spend more on health insurance? Intelligence, 52, 1-8.

Burhan, N. A. S., Razak, R. C., Salleh, F., \& Tovar, M. E. L. (2017). The higher intelligence of the 'creative minority'provides the infrastructure for entrepreneurial innovation. Intelligence, 65, 93106.

Carris, R., \& Colin, M. A. (1997). Insurance fraud and the industry response. Cpcu Journal, 50, 92-103. 
INTERNATIONAL JOURNAL OF ACADEMIC RESEARCH IN BUSINESS AND SOCIAL SCIENCES

Vol. 8, No. 12, Dec, 2018, E-ISSN: 2222-6990 @ 2018 HRMARS

Chiappori, P. A., \& Salanie, B. (2000). Testing for asymmetric information in insurance markets. Journal of political Economy, 108(1), 56-78.

Clare, S. K., Jenson, W. R., Kehle, T. J., \& Bray, M. A. (2000). Self-modeling as a treatment for increasing on-task behavior. Psychology in the Schools, 37(6), 517-522.

Dean, D. H. (2004). Perceptions of the ethicality of consumer insurance claim fraud. Journal of Business Ethics, 54(1), 67-79.

Derrig, R. A., \& Krauss, L. K. (1994). First steps to fight workers' compensation fraud. Journal of Insurance Regulation, 12(3), 390.

Dionne, G. (Ed.). (2000). Handbook of insurance (pp. 155-183). Boston: Kluwer Academic Publishers.

Dionne, G., \& St-Michel, P. (1991). Workers' compensation and moral hazard. The Review of Economics and Statistics, 236-244.

Gepp, A., Wilson, J. H., Kumar, K., \& Bhattacharya, S. (2012). A comparative analysis of decision trees vis-a-vis other computational data mining techniques in automotive insurance fraud detection. Journal of data science, 10(3), 537.

Huppertz J, Arenson S, Evans R. An application of equity theory to buyer-seller exchange situations. J Mark Res 1978;15:250-60 May.

Lamb, R. B. (1999). Ethics in financial services. Business and Society Review, 104(1), 13-17.

Mommaerts, C. (2015). Long-term care insurance and the family. unpublished, November.

Niemi, H. (1995). Insurance fraud. European Journal on Criminal Policy and Research, 3(1), 48-71.

O'Fallon, M. J., \& Butterfield, K. D. (2005). A review of the empirical ethical decision-making literature: 1996-2003. Journal of business ethics, 59(4), 375-413.

Okura, M. (2013). The relationship between moral hazard and insurance fraud. The Journal of Risk Finance, 14(2), 120-128.

Shavell, S. (1979). On moral hazard and insurance. In Foundations of Insurance Economics (pp. 280301). Springer, Dordrecht.

Stiglitz, J. E. (2009). The current economic crisis and lessons for economic theory. Eastern Economic Journal, 35(3), 281-296.

Tennyson, S. (1997). Economic institutions and individual ethics: A study of consumer attitudes toward insurance fraud. Journal of Economic Behavior \& Organization, 32(2), 247-265.

Trevino, F. M., Moyer, M. E., Valdez, R. B., \& Stroup-Benham, C. A. (1991). Health insurance coverage and utilization of health services by Mexican Americans, mainland Puerto Ricans, and Cuban Americans. Jama, 265(2), 233-237.

Tseng, L. M., \& Kang, Y. M. (2014). The influences of sales compensations, management stringency and ethical evaluations on product recommendations made by insurance brokers. Journal of Financial Regulation and Compliance, 22(1), 26-42.

Tseng, L. M., \& Kang, Y. M. (2014). The influences of sales compensations, management stringency and ethical evaluations on product recommendations made by insurance brokers. Journal of Financial Regulation and Compliance, 22(1), 26-42.

Tseng, L. M., \& Kuo, C. L. (2014). Customers' attitudes toward insurance frauds: an application of Adams' equity theory. International Journal of Social Economics, 41(11), 1038-1054.

Tseng, L. M., \& Shih, M. F. (2012). Consumer attitudes toward false representation. Journal of Financial Crime, 19(2), 163-174. 
INTERNATIONAL JOURNAL OF ACADEMIC RESEARCH IN BUSINESS AND SOCIAL SCIENCES

Vol. 8, No. 12, Dec, 2018, E-ISSN: 2222-6990 C 2018 HRMARS

Tseng, L. M., \& Su, W. P. (2013). Customer orientation, social consensus and insurance salespeople's tolerance of customer insurance frauds. International Journal of Bank Marketing, 31(1), 38-55.

Tseng, L. M., \& Su, W. P. (2013). Customer orientation, social consensus and insurance salespeople's tolerance of customer insurance frauds. International Journal of Bank Marketing, 31(1), 38-55.

Tseng, L. M., Kang, Y. M., \& Chung, C. E. (2014). Understanding the roles of loss-premium comparisons and insurance coverage in customer acceptance of insurance claim frauds. Journal of Financial Crime, 21(3), 321-335.

Vitell, S. J., \& Muncy, J. (2005). The Muncy-Vitell consumer ethics scale: A modification and application. Journal of Business Ethics, 62(3), 267-275. 